\title{
Structural and Legal Frameworks Guiding Multi-Agency Operations and Countering Terrorism in Kenya
}

\author{
Musoma Albert Lusiola \\ Major in the Kenya Defence Forces \\ Kenya
}

\begin{abstract}
Kenya has been faced with a barrage of terror threats for the last few decades. This study sets out to assess the effects of structural and legal frameworks guiding multi-agency operations on countering terrorism in Kenya. The study question was: Are there existing or lack thereof of multi-agency strategic policies on coordination in response to international terrorism in Kenya? Based on mixed methods and exploratory research designs, the target population for the study was 3400 persons drawn from all the Kenya Defense Forces Special Operations Forces (KDF SoFs), the National Police Service (NPS) Recce squad, and AntiTerror Police Unit (ATPU) Officers, Policy Level Military, Intelligence and Police Officers as well as a few members of academia. From these, a sample of 97 was obtained. Primary data was collected using questionnaires and interviews. In addition, secondary data was obtained from library-based research of relevant literature. The data collected from questionnaires were analyzed using the Statistical Package for the Social Sciences (SPSS) version 24 while data from interviews were analyzed thematically based on the study objective. The study findings make it manifest that the existence of structural and legal frameworks guiding multi-agency operations on countering terrorism in Kenya had led to effective response through standardizations of operation guidelines, better sharing of information, joint training and exchange of best practices among the various responders. This was evidenced in the Dusit D2 Attack in which synchronization of operations showed better response to the attack by the various operational and tactical teams as compared to the Westgate Attack. The study recommends that there is need for multinational frameworks for undertaking financing and creation of joint information infrastructure for security agencies so as to reign in on international terrorism in the East African Region.
\end{abstract}

Key Words: Structural and Legal Frameworks, Multi-Agency Operations, Countering Terrorism in Kenya, International Terrorism.

\section{LIST OF ABBREVIATIONS}

9/11- September 11, 2003 Terror Attack on the USA

AMISOM- $\quad$ African Union Mission in Somalia

ATPU- Anti-Terrorism Police Unit (Kenya)

CEC- $\quad$ Commission of the European Communities

GSU- General Service Unit (Paramilitary wing of Kenya's NPS)

ICT- Information Communications Technology

KDF- Kenya Defence Forces

NPS- $\quad$ National Police Service

PFLP- Popular Front for the Liberation of Palestine

POCA- Prevention of Organized Crime Act, 2010

POCAMLA- Proceeds of Crime and Anti-Money Laundering Act

POTA- Prevention of Terrorism Act, 2012

Recce- Reconnaissance Platoon of the GSU

SLAA- Security Laws (Amendment) Act, 2014

SoF- Special Operations Forces of the KDF

SOPs- $\quad$ Standard Operating Procedures

SPSS- Statistical Package for the Social Sciences

US/USA- United States of America 


\section{INTRODUCTION}

Hanhimaki quoting Rapoport in his four waves of terrorism terms the religious wave as the modern wave. To him, although terrorism is not a new phenomenon, the modern religious wave has become an extremely organized and complex enterprise [1]. Kenya has experienced five-decades of terror. The first documented terror was the January 1976 attempted shoot down of an Israeli passenger aircraft landing in from Embakasi Airport (currently Jomo Kenyatta International Airport). The Popular Front for the Liberation of Palestine (PFLP) claimed responsibility. The flight number El-Al flight was shot at using surface-to-air missiles however, the terror attack failed [2]. The second documented terror attack was on the $31^{\text {st }}$ of December 1980. It was carried out by the same PFLP. The object of attack was the Israeli-owned Norfolk Hotel. The estimated death toll was 20 people who were celebrating the ushering of the New Year [3]. The third documented attack which was the most devastating was the 1998 bombing of the USA embassy in Nairobi. The al Qaeda terror group claimed responsibility. They carried out a coordinated attack on the USA embassies in Nairobi and Dar-es-salaam.

The 2002 attack on Israeli-owned Hotel in Kikambala carried out by al Qaeda affiliates was the $4^{\text {th }}$ documented terror attack in Kenya. It claimed the lives of 13 and caused an estimated 80 injuries [4]. In the same year, the al- Qaeda linked AlShabaab targeted an Israeli chartered plane on its' take off from Mombasa International Airport with a shoulder-launched missile. It is said that Faizul- one of the key figures in al-Shabaab- was the mastermind [5]. The common trend in all these attacks is that Kenya was a soft and secondary target. The primary target was Israel, the USA, and the West. Kenya was a softer target due to security gaps and lapses as well as its proximity to Somalia [6].

With the first-ever militarization of the Kenyan foreign policy and the eventual entry of the Kenya Defence Forces (KDF) into Somalia in 2011, Kenya has evolved to become a primary target for terror groups, especially the al -Shabaab. The 2013 West gate shopping mall attack and the DusitD2 Hotel attack in January 2019 are the two major attacks where Kenya was a primary target with western interests being peripheral [7]. In other cases, terrorists have been known to haul bombs into hotels and other crowded business areas so as to harm as many people as possible. Regrettably, no documented study has attempted to take stock of some of the measures put in place to respond to these attacks.

This current study conceptualizes that governments have various responses to international terrorism which include normative, policy and strategic frameworks as well as institutional mechanisms for sharing information during terror operations by intelligence teams and obtaining and relaying information to the intelligence community by operational-tactical teams during terror attacks. The study hypothesizes that intelligence teams and operation units face numerous challenges in sharing intelligence products. However, no documented study has investigated this conceptualized relationship. It is in this context that this current study sets out to investigate the coordination in responses to international terrorism in Kenya.

\subsection{Statement of the Research Problem}

Kenya has elaborate structural and legal frameworks guiding multi-agency operations on countering international terrorism in Kenya. Some of these include: "the Proceeds of Crime and Anti-Money Laundering Act, 2009 (POCAMLA); the Prevention of Organized Crime Act, 2010 (POCA); the Prevention of Terrorism Act, 2012 (POTA), and Security Laws (Amendment) Act, 2014 (SLAA)" [8]. These frameworks have facilitated the creation of multi-agency institutions such as the National Counter Terrorism Center, which was created by the SLAA; Anti-Terror Police Unit (ATPU), and the Joint Intelligence Analysis Center all these are to synergize and consolidate the efforts to deal with terrorism in the country. However, the fact that Kenya has such elaborate antiterrorism frameworks, sporadic terrorist attacks such as the Dusit D2 terror attack of January 2019 still happened. Although improvements in response to terrorist attacks have been recorded over time, there are some gaps that need to be investigated. For example, it is pertinent to investigate any existent gaps in the coordination of response to terrorism at strategic and higher operational realms. It is also important to find out the sufficiency of the laws governing deployment, training and interoperability of various multi-agency actors. Without studies such as this current one thus, it would remain a tall order understanding the influence of the existence or lack thereof of structural and legal frameworks guiding multi-agency operations on countering international terrorism in Kenya. This current study sets out to bridge this knowledge gap.

\subsection{Research Objective}

To examine the existing or lack thereof of structural and legal frameworks guiding multi-agency operations on countering terrorism in Kenya.

\subsection{Hypotheses}

$\mathrm{H}_{1}$ The existence of structural and legal frameworks guiding multi-agency operations on countering terrorism in Kenya has led to an effective response. 


\section{LITERATURE REVIEW}

This section presents the literature reviewed done in line with the study variable namely structural and legal frameworks guiding multi-agency operations on countering terrorism

\subsection{Empirical Literature Review}

Westby, Jody R. "Countering terrorism with cybersecurity" notes the importance of information and communication technologies (ICT) as a key enabling factor to terrorism [9]. He says that this is even compounded further by difficulty in governments to track and trace cyber communications. ICT being transnational, "there are no common global-standardized processes and procedures for the tracking and investigation of cybercrimes, and the inadequate or ineffective information sharing systems between the public and private sectors" [9]. Westby notes that although there have been massive developments in tracking and tracing capabilities globally, governments have shown a lack of goodwill in enacting laws and coming up with policies to fine-tune and operationalize these procedures. The post $9 / 11$ period saw governments tightening border security, heightened technical surveillance and enhanced their ICT counterterrorism capabilities. Westby underlines the importance of interventions across the cyberspace which has been an important component of counterterrorism measures as shown Raneta and others [10].

Raneta, Lawson Mack, and Michael J. Kelly in "Equal Justice in the Balance: America's Legal Responses to the Emerging Terrorist Threat" assert that in responding to terror acts, governments have put in place several legal measures to combat it [10]. In the USA, the September 11 terrorist attacks have brought into light various legal instruments among them are "the Aviation and Transportation Security Act, the Transport Security Act, the Enhanced Border Security and Visa Entry Reform Act among others. All these are aimed at reinforcing border security." He further adds that the Public Health Security and Bioterrorism Preparedness and Response Act is a key response law [10].

Haque, M. Shamsul. "Government Responses to Terrorism: Critical Views of Their Impacts on People and Public Administration." Focuses on the measures put in place by Western countries in responding to terror acts. They assert that "such states have strengthened and expanded antiterrorist laws since September 11 [11]. For instance, the European Commission adopted the Framework Decision on Combating Terrorism (2001)." These frameworks amongst other things define terrorism. This is key to ensuring that during the response, all actors have a common understanding of the phenomenon. The framework also dictates the penalties and sanctions to be meted on various groups or individuals. It goes ahead to explain "the extradition procedures and means of exchanging information to be followed by the member states of the European Union (CEC 2001)" [11]. Haque paints a clear picture on how policy and legal frameworks can be leveraged to deal with international terrorism.

A country focus shows that Canada enacted the Anti-Terrorism Act (2001), which "prescribes measures to define and designate terrorist groups and activities, prosecute and punish terrorists, facilitate the use of electronic surveillance, and allow the arrest and detention of suspected terrorists." The Britons, on the other hand, adopted "the Anti-Terrorism, Crime and Security Act (2001)." The Australian government on their part introduced amongst other amendments to their already existing security and anti-terrorism laws, "the Security Legislation Amendment (Terrorism) Act (2002) and Border Security Legislation Amendment Act (2002).”

Ronald Crelinsten and Alex Schmid, "Western Responses to Terrorism: A Twenty- Five Year Balance Sheet" categorizes counter-terrorism responses into two: "the criminal justice model and war model." In the criminal justice model, terrorism is dealt with like a crime. This means the police, prosecution units, judiciary amongst other judicial systems are the key players. Primary responders in this model are the police and affiliated units (e.g. GSU, ATPU, RECCE Company of GSU in Kenya) [12].

The Second is the war model. In this response model, terrorism is considered as an act of war. Thus, the main response is the military. The primary responders are usually military elite units e.g. special operations forces, air retaliatory attacks, air responses, infantry occupations among other military campaigns [12]. There is emerging a modern model that merges these two. The police are involved in arrests, detentions, interrogations and prosecutions whereas the military supports the police in track and trace processes as well as responding to actual terror activities [12].

Carmichael, "Of Beasts, Gods and Civilized Men: The Justification of Terrorism and of Counterterrorist Measures" looks at state response from a strategic perspective. To him, the state must respond swiftly but in observance of human rights. He gives an example of hostages and says that, as the state responds, it must consider the safety of hostages even though the very terrorists have the ability to kill them. He continues to assert that, if states will respond without observance of human rights, then the states will be as savage as the terrorists themselves.

Schmid, "Countering Terrorism in the Netherlands" opines that, the greatest dilemma governments have in responding to terror events is the balance between how much information to release to the media vis-a-vis trying to observe operation security [13]. Negative media coverage aids terrorists a lot. In the Westgate terror attack, the Kenyan media amplified their coverage to such an extent that they aided the al Shabaab to get information that aided the terrorist inside the mall to know what was going on outside. Also, too much media coverage tends to give the terrorists the oxygen they need. It aids them in recruitment, funding, networking, raising stakes for validity and negotiations. 
On the contrary, if the government denies media basic information, it leads to speculation thus discrediting the government. Imposing a ban on media could even lead to legal tussles since it infringes on some of the constitutional rights of both the media houses and the citizens who have a right to be informed [13].

Spanish Organic Law No.8 empowers judges to close down media houses which are support terrorism [14]. Article 129a, Section 3 of the German Penal Law "prohibits the advertising of terrorist manifestos and propaganda" [15]. Kenya has an open clause towards what media can cover during terror attacks. The Kenyan law only talks of responsible coverage which leaves it open for the media house to define what is responsible and what is not [16]. This shows a glaring vacuum on how to ensure such responsibility; which can have negative ramifications on national security.

Durmaz, et al. "Understanding and Responding to Terrorism," gives two principals that should be considered when focusing on legal policing issues in the fight against terror. These are "societal protection (including culture, people, and property) and ensuring human rights and the rule of law." To do this effectively, we must have a common definition of terrorism. They say that what's more important is what laws states put in place to protect the two principles. They call these preventive measures. They break them down into; criminal investigation measures, terrorist investigations, penalties, punishments meted, the net effect of the outcomes of these punishments [17].

Pedahzur, Ami "The Israeli Secret Services and the Struggle against Terrorism the Literature of Counterterrorism" analyses the war model, the criminal-justice model, and the reconciliatory model of terrorism. To him, the war model regards terrorism as "an act of warfare based on revolution." The criminal-justice model sees terrorism as "a criminal act, whereas the reconciliatory model sees it as a political problem. To Pedahzur, these are the modes with which states can respond to terrorism" [18].

The war model has the military as the primary responder with the aim of crushing the terror groups. The criminal justice model puts the police agencies as main responders with the judiciary facilitating the police actions in terms of convictions and penalties. The reconciliatory use policy, diplomacy, and politics to negotiate terrorism with a focus on its root causes. Ami goes ahead to assert that these 3 models co-exist and can be mixed at some stage. As the police as arresting and interrogating terrorists, the military could bomb their training bases as diplomats and politicians negotiate deals [18].

Jeanne Giraldo, and Harold Trinkunas “Terrorism Financing and State Responses: A Comparative Perspective," note that the greatest steppingstone to terrorism is financing. If governments can successfully choke terror group financing, then they can defeat terrorists [19]. However, to do this successfully, government departments like Defence, Intelligence, Police, treasury, banks, and the private sector must synergize and coordinate their efforts to choke the financial supply lines of the terrorists. The post-September 11, 2001 attack brought into light a lot of studies about the financing of terrorist groups. Governments have come up with new policies to deal with financing. In Kenya, the government has enacted the terror financing act, anti-money laundering act, and it has also adopted several international treaties like "the international convention for the suppression of the financing of terrorism (1999), Security Council resolution 1373-2001" [20].

Richelson, Jeffrey, and Michael L. Evans, "Terrorism and U.S. Policy" observe that there were a series of international antiterrorist conventions that had emerged before the 9/11 terror attack. This included "the Convention for the Suppression of Unlawful Acts against the Safety of Aircraft in 1971, the Convention against the Taking of Hostages in 1979, the Convention for the Suppression of Terrorist Bombings in 1997, and the Convention for the Suppression of Financing Terrorism in 1999” [21]. In the USA alone, the government came up with various acts and documents. Some include "Managing Terrorist Incidents (1982), National Program for Combating Terrorism (1986), U.S. Policy on Counterterrorism (1995), and Terrorism, the Future, and U.S. Foreign Policy (2001)" [21].

Beckam James, "Comparative legal approaches to homeland security and anti-terrorism" notes that "the Patriot Act amended 12 other acts and regulations ranging from laws on money laundering to telemarketing and consumer fraud acts in the United States" [22]. This was in response to the September 11 bombings. In Germany in 2002, the government implemented the Law for fighting international terrorism. This led to the modification of several security statutes [23]. In contrast, the Spanish government, even after the Madrid train bombings, did not implement any legislation that explicitly addressed the threat of international terrorism. It instead focused on legislating laws that "increased the maximum punishment for terrorist crimes" [23]. Beckam considers "Legislative responses to international terrorism to consist of a combination of new laws and amendments to existing laws" [22].

Ali A. Mazrui, "Afro-Arab Crossfire: Between the Flames of Terrorism and the Force of Pax-Americana," asserts that the greatest victims who bear the brunt of anti- America terrorism are the Middle East and Africa [24]. However, he says that the difference between the two is that the Middle East has been terrorized by the American government efforts in 'war against terrorism'. Africa has been a retaliatory punching bag for terrorists when they are unable to retaliate against America's homeland or its strong allies.

Mazrui borrows from Rapoport's "Four Waves of International Terrorism" and asserts that Africa and the Middle East were both subjected to imperialism forcing them to react in an attempt to shrug off the oppressors [1]. This was considered as an act of terror by the west. Mazrui finalizes by saying that the middle easterners have a keen memory of the atrocities of the west and have fiercely guarded their culture, values, and traditions against western hegemonic tendencies of pushing western cultures 
down other nations' throats [24]. He says that Africa has a short memory and myopic vision that irrespective of the western atrocities from the colonial times, they still are puppets of the west and thus have been made victims of the western ideology of "the war on terror."

Macharia Munene, "The Challenge of al Shabaab," gives a dichotomy of the challenges of al Shabaab justification of their jihad in Kenya [25]. The first threat of jihad is the physical threat and destruction of property. This is mainly as a consequence of their military guerrilla operations in Kenya or on Kenyan soldiers in Somalia under the general umbrella of AMISOM. Munene considers the second challenge to be the psychological threat to the minds of the people, and to their sociocultural and economic way of life. This threat has an even bigger impact than the first since it has a medical connotation to it.

\section{RESEARCH METHODOLOGY}

The study adopted mixed methods and exploratory research designs. Exploratory research designs fit well where there are limited or fewer studies, important for obtaining background information about a given topic and is flexible, able to address a variety of research questions. According to Creswel [26] "mixed-method research employs both qualitative and quantitative research designs to complement each other by overcoming the weaknesses of each other."

The target population was all the members of the KDF SoFs, the NPS Recce Squad, and ATPU Officers, policy level military and police officers as well as a few members of academia. The target population is estimated at 3400 personnel. The sample size for this study was obtained from a sampling formula by Yamane [27];

$n=\frac{N}{1+N(e)^{2}}=97.1$

Where,

$\mathrm{n}=$ the sample size

$\mathrm{N}=$ the size of the population

$\mathrm{e}=$ the error of $10 \%$

The calculation from a population of 3400 was 97 .

Therefore, a sample of 97 respondents was chosen from the various security agencies as indicated in Table 1 below.

Table 1 Sample Size Categories

\begin{tabular}{|l|c|c|l|}
\hline \multicolumn{1}{|c|}{ Operations Teams } & Population Size & Sample Size & Sampling Technique \\
\hline KDF SoF terror-related & 2,000 & 45 & Purposive Sampling \\
\hline NPS Recce terror-related & 400 & 12 & Purposive Sampling \\
\hline ATPU Officers & 800 & 20 & Purposive Sampling \\
\hline Policy Level Officers & 150 & 10 & Purposive Sampling \\
\hline Members of Academia & 50 & 10 & Purposive Sampling \\
\hline TOTAL & $\mathbf{3 , 4 0 0}$ & $\mathbf{9 7}$ & \\
\hline
\end{tabular}

Validity is key in making sure that "the instrument measures what is intended to measure" [28]. To ensure this, the data collection instruments were submitted for expert review. Reliability, on the other hand, ensures consistency, dependability or trustworthiness in measurements of the desired study variables. To aid this, the researcher employed a test-retest technique to guaranty it.

This study employed primary as well as secondary data collection techniques. Primary data was collected from the respondents using mainly questionnaires and interviews. On its part, secondary data was obtained from library-based research via books, e-books, journals, government publications, and published thesis, among other reputable academic publications.

The data collected from questionnaires were analyzed using the Statistical Package for the Social Sciences (SPSS) version 24. The findings were presented in descriptive statistics, tables, graphs, charts and inferential statistics. On its part, data from interviews were analyzed thematically based on the objectives so as to establish the key themes and trends from which findings, conclusions, and recommendations were drawn.

\section{RESULTS AND ANALYSIS}

This section presents the findings of the study. The study sought to, "to examine the existing or lack thereof of structural and legal frameworks guiding multi-agency operations on countering terrorism in Kenya." The findings obtained from questionnaires, interviews and desk review of extant literature are presented in the following section. 


\subsection{Laws on the Use of Legal Instruments of Violence}

The respondents were presented with the statement, "Kenyan security forces often use their legal instruments of violence to terrorize citizens in antiterrorism campaigns and these challenges the cooperation of locals in the fight against terrorism." The findings obtained show that there were instances in which the security forces misused their instruments as shown by most of the respondents $(37.7 \%)$ who agreed with the statement. This shows that the existent structural and legal frameworks guiding multiagency operations were either weak or poorly enforced. This is in line with Boaz Ganor, in "Defining Terrorism: Is One Man's Terrorist another Man's Freedom Fighter?" who argues that governments had used their legal instruments of violence to terrorize their citizens [29]. In this regard, there could be poor protection of civilians in the fight against terrorism [30]. As a result, winning the support of locals in the fight against terrorism could be compromised as argued by Jones and others [31]. These findings are presented in Figure 1.

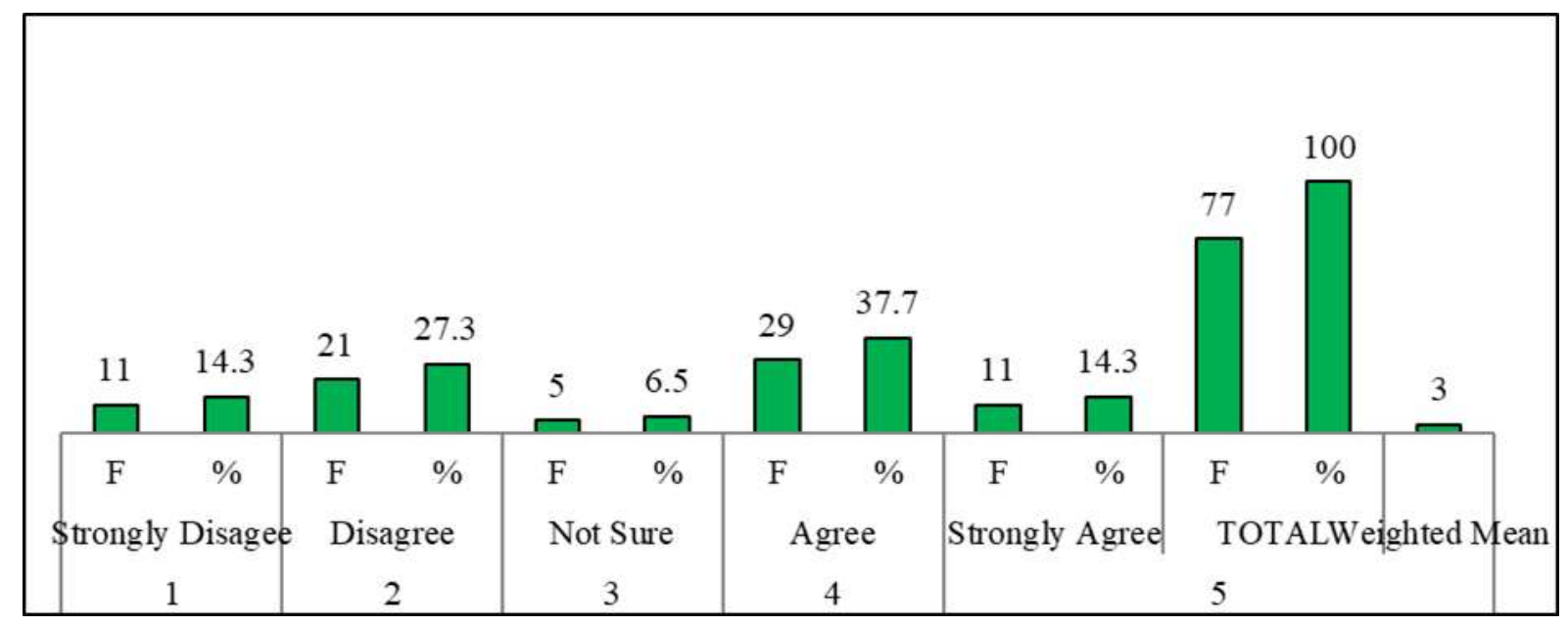

Figure 1 Laws on the Use of Legal Instruments of Violence

\subsection{Efforts to Unify the Measures Taken to Prevent, Punish and Combat Terrorism in Kenya}

The respondents were presented with the statement, "there has been an increased drive in unifying the measures taken to prevent, punish and combat terrorism in Kenya." Most of the respondents (44.2\%) strongly agreed with it. This means that there were various legal and structural frameworks put in place by Kenya for the purposes of ensuring a synchronized and effective response to terrorism in Kenya. As a result, there could lead to improvements in coordination in the fight against terrorism. Some of these frameworks as elicited by Kibet in a study titled, "Terrorism and Kenya's Foreign Policy: A Contextual Analysis," include "Prevention of Organized Crime Act 2010, Proceeds of Crime and Anti-Money Laundering Act 2011, and Prevention of Terrorism Act 2012" which was amended in 2013 to "strengthen the criminalization of financing acts of terrorism" [32]. However, some of these legislations - "Prevention of Organized Crime Act 2010 [33], Proceeds of Crime and Anti-Money Laundering Act 2011 [34], and Prevention of Terrorism Act 2013" [35] - had not totally sealed loopholes in terror response processes as shown in Figure 2.

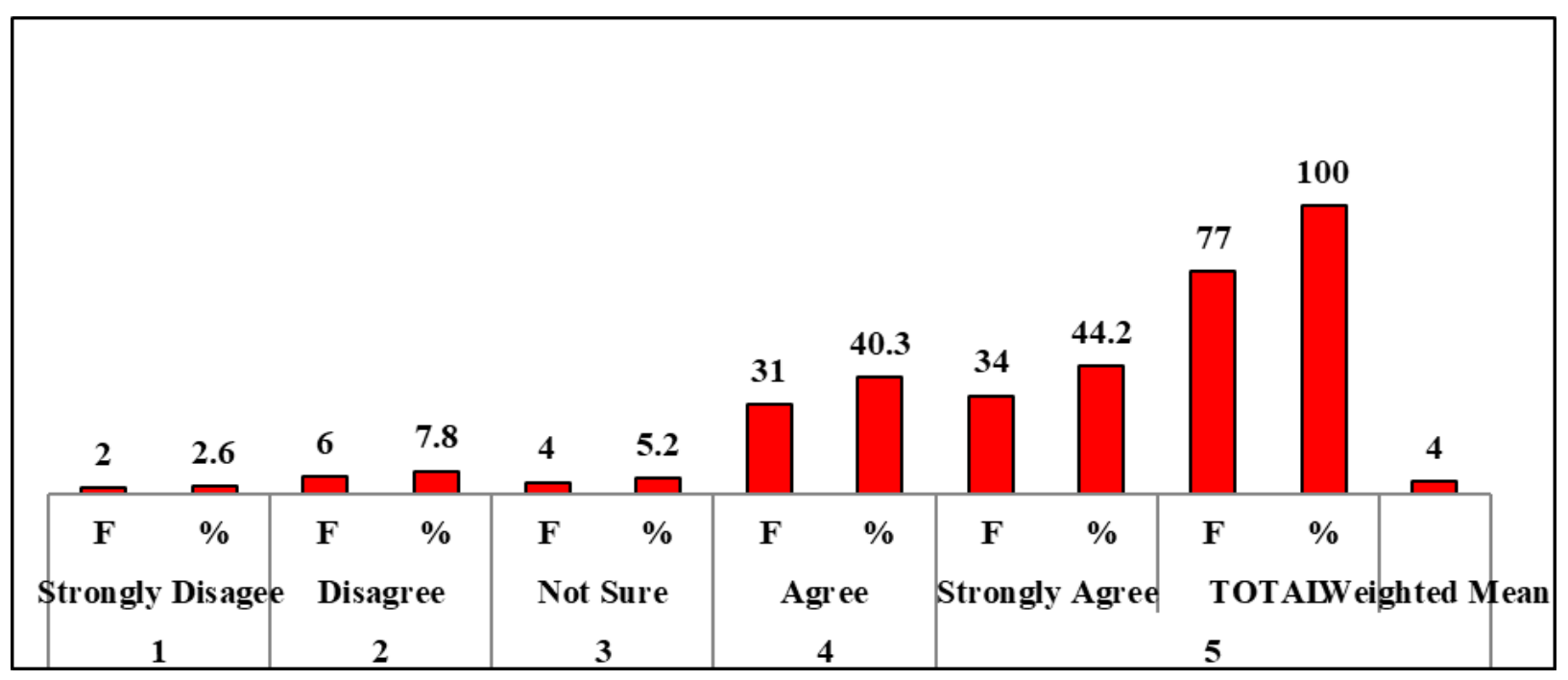

Figure 2 Efforts to Unify the Measures Taken to Prevent, Punish and Combat Terrorism in Kenya 


\subsection{Legal Frameworks on Media Coverage during Terror Attacks}

The respondents were posed with the statement, "due to the open clause towards what media can cover during terror attacks, Kenya has not been able to ensure operational security in response to terrorism." As shown in Figure 3, almost half of the respondents $(48.1 \%)$ agreed with the statement. This shows that response to terror attacks was often challenged by leaked information on during operations [36]. Although this effect was less pronounced during the Dusit D2 Attack in comparison with the West Gate Attack, the modus operandi of the mass media could still enhance the morale of terrorists under Kenya's current legal framework.

Simon, Goldberg, et al in "the Use of Social Media in the Westgate Mall Terror Attack in Kenya with a special focus on Twitter," found that the September 2013 attack in which 67 persons lost their lives; twitter was extensively used "to share information between the government, emergency responders and the public" [37]. This often-created confusion with some key tactical information falling into the hands of the terrorists as argued by Gonzales-Herrero and others [38]. As such, there was a need to expand the legal and structural frameworks guiding multiagency response to terrorism to reign in on interferences from the mass media while still safeguarding freedoms of expression and access to information.

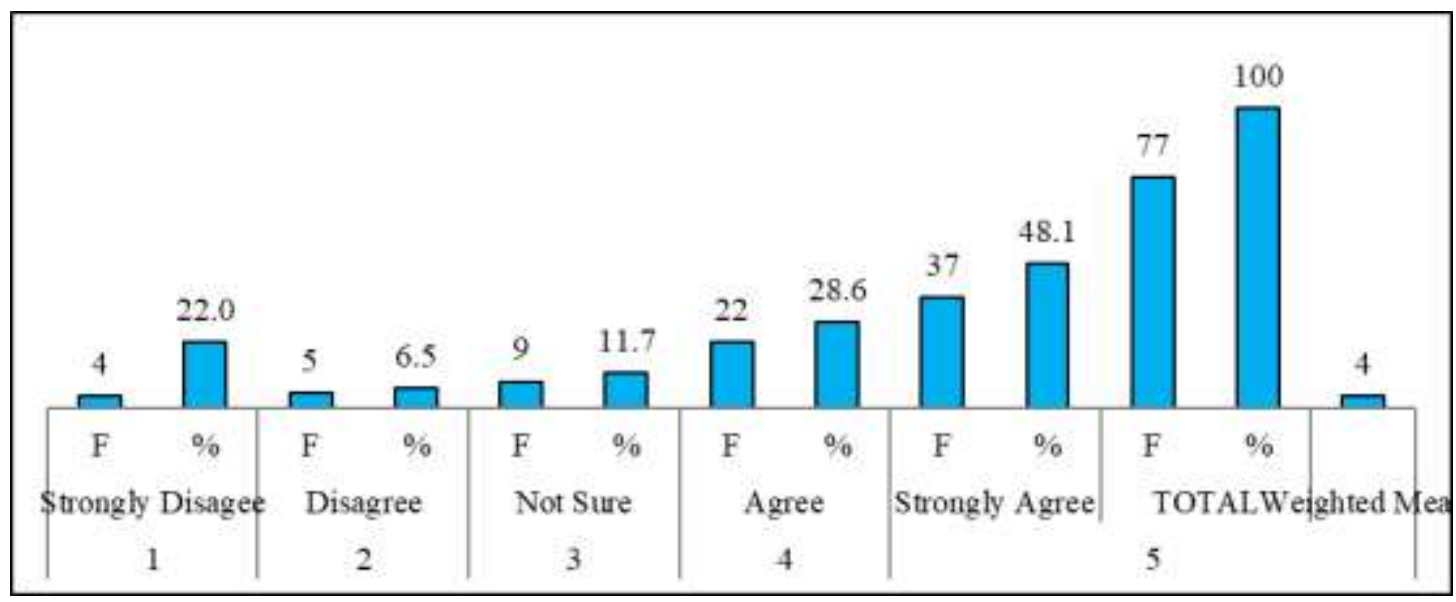

Figure 3 Legal Frameworks on Media Coverage during Terror Attacks

\subsection{Clear Understanding of the Terror Financing Act and Anti-Money Laundering Act}

The respondents were presented with the statement, "there is a clear understanding of the terror financing act and antimoney laundering act by the various intelligence teams in Kenya." This was pertinent since the lack of understanding of these acts could curtail intelligence sharing on terrorist organizations and their plans. This was aggravated by hierarchical challenges in the application of law [39]. Most of the respondents (42.9\%) strongly disagreed with the statement. This shows that there was poor understanding of the act as posited by Kibet [32]. Consequently, the capacity of multi-agency response teams to promptly share information on terror financing could be compromised; creating loopholes that could be exploited by terrorists [40].

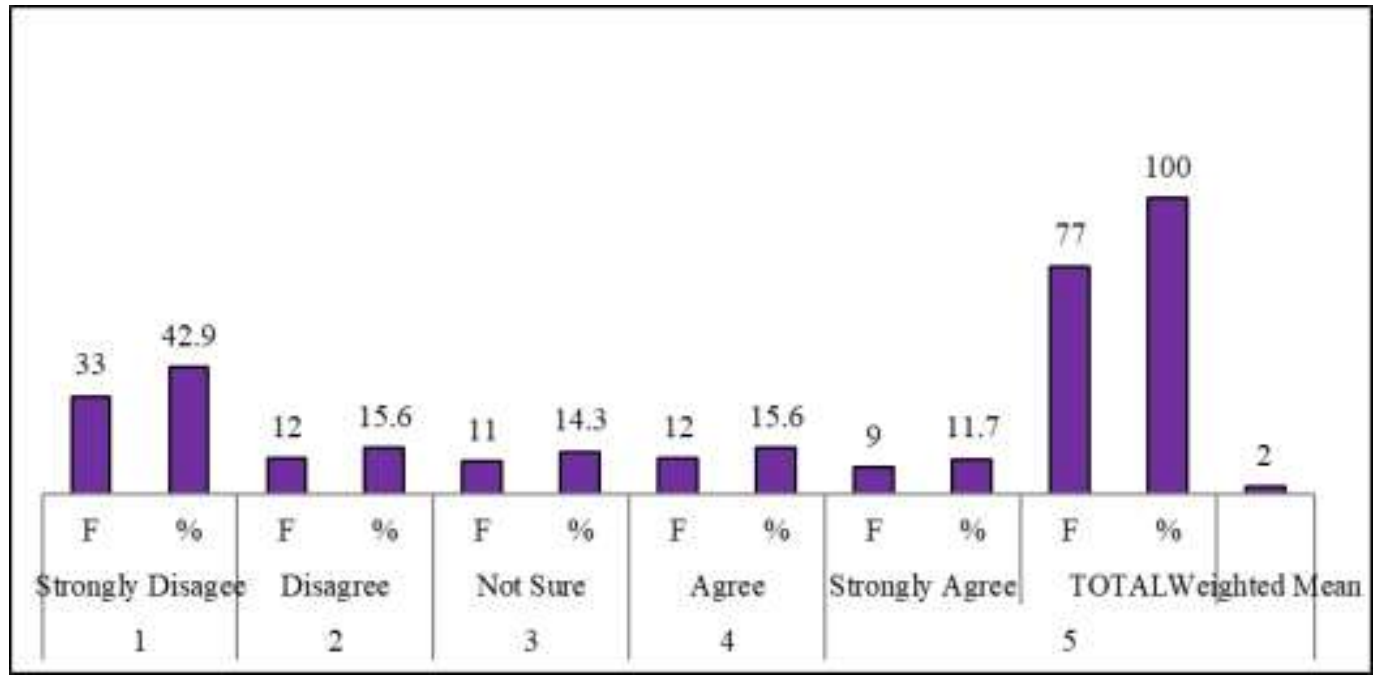

Figure 4 Clear Understanding of the Terror Financing Act and Anti-Money Laundering Act 
The respondents were also presented with the statement, "support from international security frameworks like the international convention for the suppression of the financing of terrorism (1999) and Security Council resolution 1373-2001 has helped Kenyan intelligence teams in the fight against terrorism." Almost half of the respondents (48.1\%) strongly disagreed with the statement. Although $39.2 \%$ of the respondents either agreed or strongly agreed with the statement, it can be argued that Kenya was yet to fully enjoy support from international security frameworks such as suppression of the financing of terrorism (1999) [41] and Security Council resolution 1373-2001 [42] among others on the fight against terrorism.

Evidently, Kenyan security agents benefitted from access to intelligence on possible terror attacks and the operations of terrorist organizations and their cells. However, the fact that terrorist attacks did still take place is indicative of the fact that the country was yet to fully benefit from some of the frameworks as posited by Jeanne Giraldo, and Harold Trinkunas in "Terrorism Financing and State Responses: A Comparative Perspective" [19]. However, some efforts had been undertaken such as "the enactment of the Terror Financing Act and the Anti- Money Laundering Act."

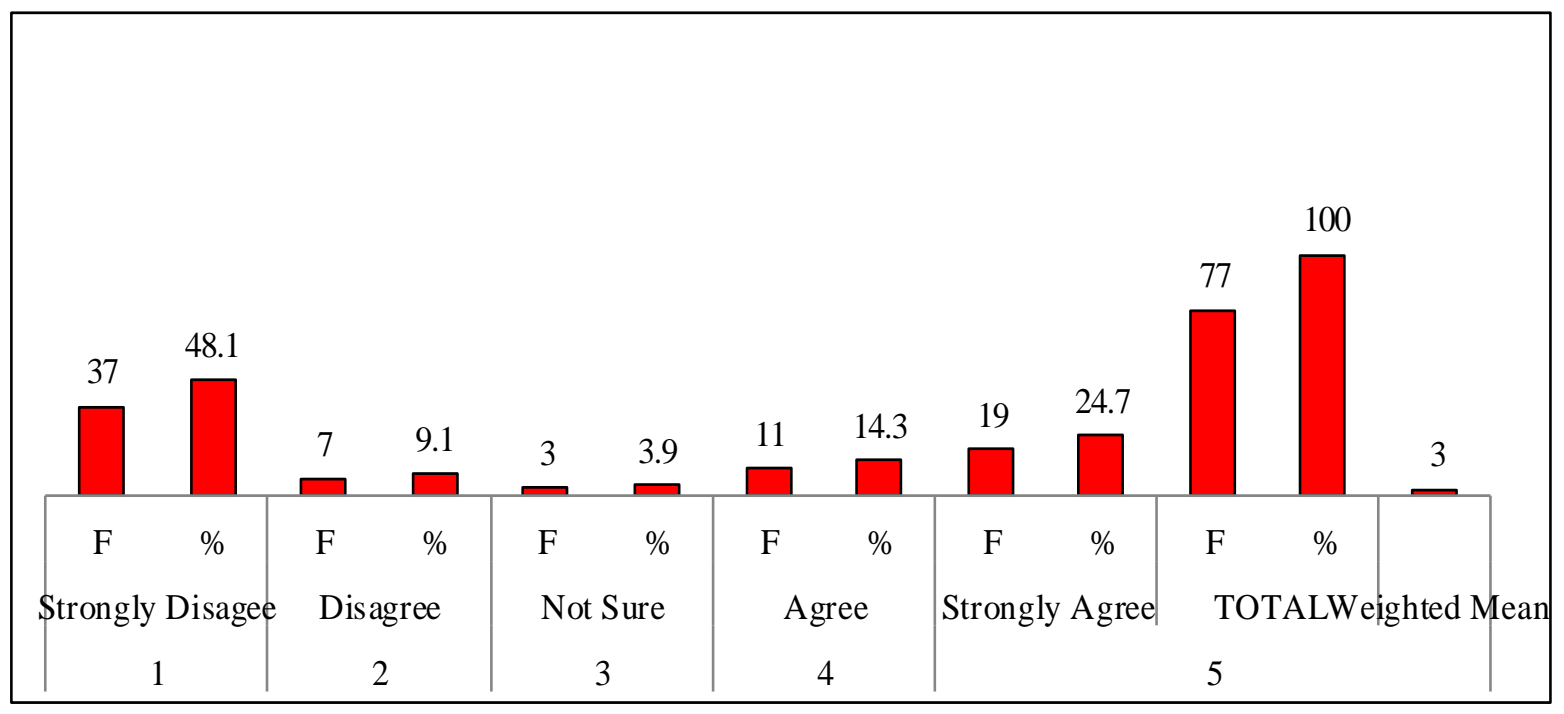

Figure 5 Kenya Enjoys Support from International Security Frameworks

\subsection{Kenya as Part of International Counterterrorism Efforts}

When presented with the statement, "Kenya is part of international efforts aimed at training together, commonizing policies, legislating laws and signing treaties on extradition, sharing of intelligence, forming multiagency task forces, creating combined and joint centers of operations and intelligence among other areas," most of the respondents (44.2\%) strongly agreed. This shows that tactical and intelligence teams took part in training together [43] and had adopted some common policies [44] and laws that could enhance sharing of intelligence and joint operations in response to terrorist attacks as argued by Francis Kipkurui Arap Sang in his book chapter titled Kenya in "International police cooperation: a world perspective" [45].

In this context, it can be argued that Kenya was likely to report gains in her responsive to terror attacks as witnessed in the Dusit D2 Attack where support from international partners led to a reduction in the number of casualties as well as the time taken to neutralize the attack. These findings are shown in Figure 6. 


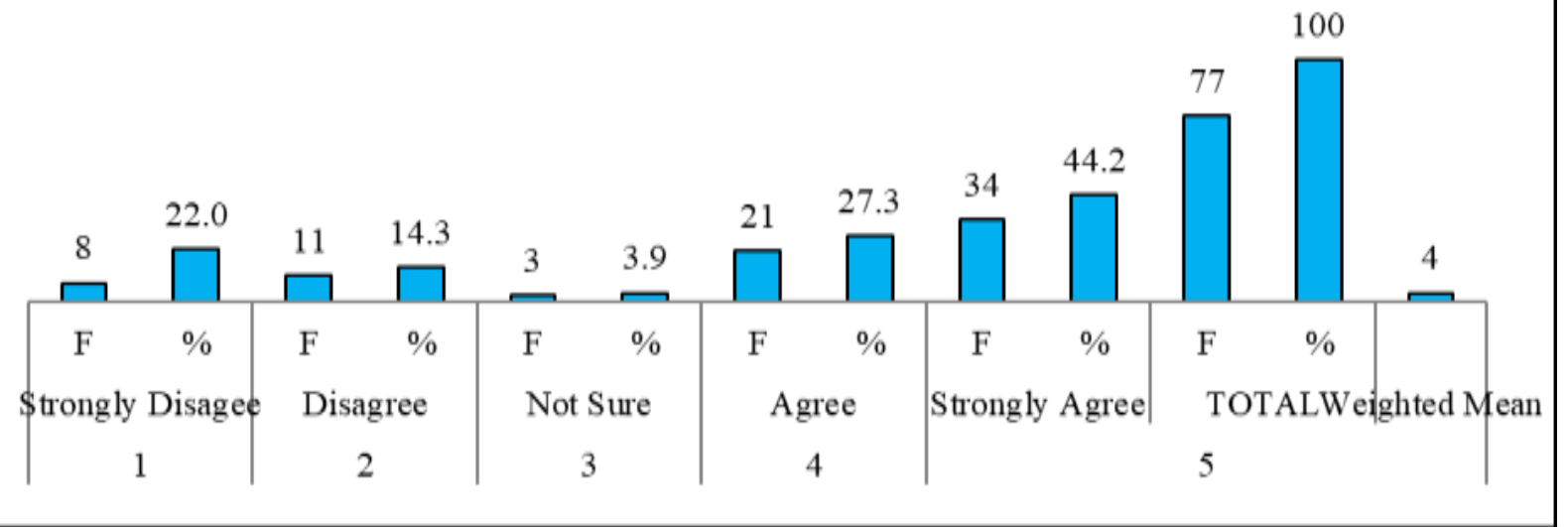

Figure 6 Kenya as Part of International Counterterrorism Efforts

\subsection{Multi-Lateral Training Institutes}

Lastly, the respondents were presented with the statement, "multi-lateral training institutes such as the international peace support training center in Karen have enhanced the capacity of local intelligence and tactical teams to respond to terror threats." More than half of the respondents (51.9\%) strongly agreed with the statement. This shows that these training institutions had led to the exchange of best practices and expertise in the fight against terrorism as posited by Bakker, Maley, and Boeke [46]. As a result, Kenya had seen improvements in the capacity of local security agents to respond to terrorist threats as witnessed in Sri Lanka among other parts of the world [47]. These structural frameworks and the associated security arrangements were thus pivotal in equipping local intelligence and tactical teams to undertake productive multi-agency response to terrorism [45].

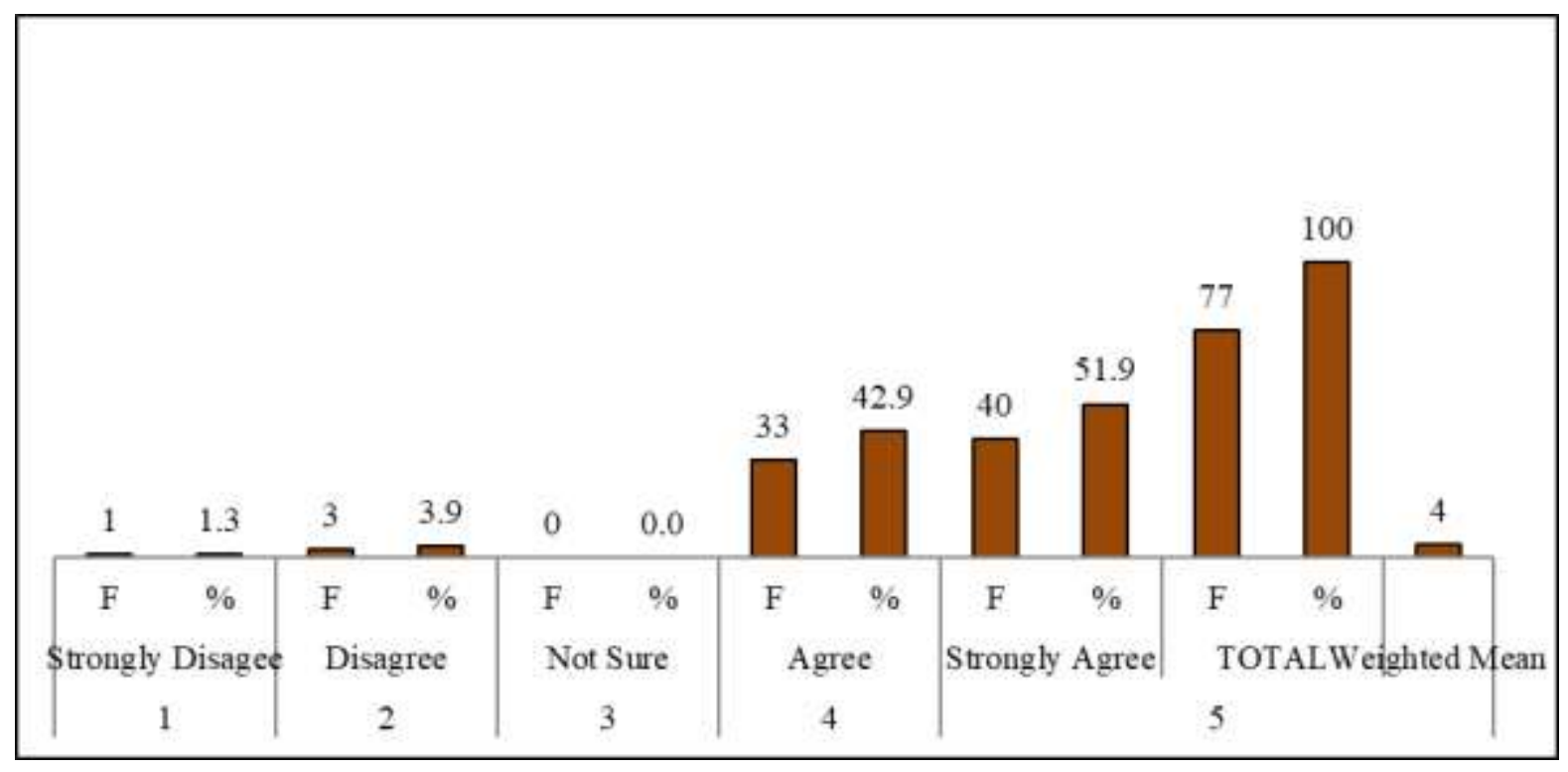

Figure 7 Multi-Lateral Training Institutes

\subsection{Findings from the Open-Ended Questions and Interviews}

The respondents were presented with the question, "in which other ways do you rate the structural and legal frameworks guiding multi-agency operations on countering terrorism in Kenya?" In the same accord, the interviewees were posed with the question, "are there structural and legal frameworks guiding multi-agency operations on countering terrorism in Kenya?" The emanating responses show that the country had various legal and structural arrangements aimed at enhancing the effectiveness of such operations. These included operation guidelines in all agencies and special task forces that had similar or related training. These guidelines created an avenue for smooth intelligence sharing as well as platforms under which the challenges experienced in joint operations could be solved as argued by Maluki [48].

This had played crucial rules in reducing blue on blue attacks and other negative repercussions emanating from disjointed multi-agency responses during terrorist attacks [49]. The existent legal and structural frameworks had also enabled Kenya to get 
into partnerships with international allies in the fight against terrorism. This had born fruits in the information sharing [39], prosecution, freezing of terrorist assets and repatriation of suspects among others. Kenya had also been able to cooperate with her neighbours in cross-border operations targeting terrorist cells and their operations.

\subsection{Hypothesis Testing}

On the basis of the preceding discourse, the study accepts the hypothesis that "the existence of structural and legal frameworks guiding multi-agency operations on countering terrorism in Kenya has led to an effective response." This had been evidenced in the Dusit D2 Attack in which synchronization of operations showed better response to the attack by the various operational and tactical teams as compared to the Westgate Attack as argued by Maluki [48]. As such, there was need to strengthen these frameworks so as to enhance unified response to international terrorism.

\section{CONCLUSION AND RECOMMENDATIONS}

\subsection{Conclusion}

On the structural and legal frameworks guiding multi-agency operations on countering terrorism in Kenya, the findings show that there were instances in which the security forces misused their instruments. As such, the existent structural and legal frameworks guiding multiagency operations were either weak or poorly enforced. There could thus be poor protection of civilians in the fight against terrorism.

There were various legal and structural frameworks put in place by Kenya for the purposes of ensuring a synchronized and effective response to terrorism in Kenya. As a result, there could lead to improvements in coordination in the fight against terrorism. Some of these frameworks included "the Prevention of Organized Crime Act 2010, Proceeds of Crime and Anti-Money Laundering Act 2011 [34], and Prevention of Terrorism Act 2012" which was amended in 2013 to "strengthen the criminalization of financing acts of terrorism." However, some of these legislations had not totally sealed loopholes in terror response processes.

Response to terror attacks was often challenged by leaked information on during operations. Although this effect was less pronounced during the Dusit D2 Attack in comparison with the West Gate Attack, the modus operandi of the mass media could still enhance the morale of terrorists under Kenya's current legal framework. This often led to confusion with some key tactical information falling into the hands of the terrorists. As such, there was a need to expand the legal and structural frameworks guiding multiagency response to terrorism to reign in on interferences from the mass media while still safeguarding freedoms of expression and access to information. There was a poor understanding of the act as posited by Kibet [32]. Consequently, the capacity of multi-agency response teams to promptly share information on terror financing could be compromised; creating loopholes that could be exploited by terrorists.

Evidently, Kenyan security agents benefitted from access to intelligence on possible terror attacks and the operations of terrorist organizations and their cells. However, the fact that terrorist attacks did still take place is indicative of the fact that the country was yet to fully benefit from some of the frameworks such as the suppression of the financing of terrorism (1999)security council resolution 1373-2001. However, some efforts had been undertaken such as the enactment of the Terror Financing Act and the Anti- Money Laundering Act.

Tactical and intelligence teams took part in training together and had adopted some common policies and laws that could enhance the sharing of intelligence and joint operations in response to terrorist attacks. It can thus be argued that Kenya was likely to report gains in her responsive to terror attacks as witnessed in the Dusit D2 Attack where support from international partners led to a reduction in the number of casualties as well as the time taken to neutralize the attack.

Training institutions had led to the exchange of best practices and expertise in the fight against terrorism. As a result, Kenya had seen improvements in the capacity of local security agents to respond to terrorist threats. These structural frameworks and the associated security arrangements were thus pivotal in equipping local intelligence and tactical teams to undertake productive multi-agency response to terrorism.

The country had various legal and structural arrangements aimed at enhancing the effectiveness of such operations. These included operation guidelines in all agencies and special task forces that had similar or related training. These guidelines created an avenue for smooth intelligence sharing as well as platforms under which the challenges experienced in joint operations could be solved as argued by Maluki [48]. This had played crucial rules in reducing blue on blue attacks and other negative repercussions emanating from disjointed multi-agency responses during terrorist attacks. The existent legal and structural frameworks had also enabled Kenya to get into partnerships with international allies in the fight against terrorism. This had born fruits in the information sharing, prosecution, freezing of terrorist assets and repatriation of suspects among others. Kenya had also been able to cooperate with her neighbors in cross-border operations targeting terrorist cells and their operations.

Based on the study findings, the study accepts the hypothesis that "the existence of structural and legal frameworks guiding multi-agency operations on countering terrorism in Kenya has led to an effective response." This had been evidenced in the Dusit D2 Attack in which synchronization of operations showed better response to the attack by the various operational and 
tactical teams as compared to the Westgate Attack. There was thus a need to strengthen these frameworks so as to enhance unified response to international terrorism.

\subsection{Recommendations}

Based on the findings of the study, the following recommendations were made. There is a need for multinational frameworks for undertaking financing and creation of joint information infrastructure for security agencies so as to reign in on international terrorism in the East African Region. This is pertinent since financing remains a major challenge to multiagency coordination in the region. Also, different SOPs between various security agencies at state level creates a challenge that could confound trans-border cooperation in response to international terrorism. It is thus important to create a joint regional infrastructure that takes cognizance of these local realities and that proffers tangible remedial actions.

\section{REFERENCES}

[1] Rapoport, D.C. (2013). "The Four Waves of Modern Terror: International Dimensions and Consequences” in Hanhimäki, Jussi and Bernhard Blumenau, eds., An International History of Terrorism: Western and Non-Western Experiences. London: Routledge.

[2] Hornsby, C. (2012). Kenya: A History since Independence. London/New York: I.B. Tauris, 321

[3] Mogire, E., \& Mkutu, K.A. (2011). Counterterrorism in Kenya. Journal of Contemporary African Studies, 29 (4), 474.

[4] Criswell, D. (2018). Preparing for a Complex Coordinated Terrorist Attacks. Domestic Preparedness. Accessed on April 4, 2018 from https://www.domesticpreparedness.com/preparedness/preparing-for-a-complex-coordinated-terrorist-attack/ Accessed: 14.04 .18

[5] Shinn, D.H. (2007). Al-Qaeda in East Africa and the Horn. Journal of Conflict Studies, 27 (1), 56.

[6] Munene, M. (2013). We Will Recover from Terrorist Attack. Business Daily, [30th September 2013].

[7] Asamba, M. (2019, 7th January). Anger, pain in the aftermath of Dusit attack. Standard Digital. https://www.standardmedia.co.ke/article/2001309766/anger-pain-in-the-aftermath-of-dusit-attack-photos

[8] Government of Kenya. [2020]. Acts and Regulations. Financial Reporting Center. Accessed on June 12, 2020 from http://frc.go.ke/downloads.html

[9] Westby, J.R. (2006). "Countering Terrorism with Cyber Security," paper for the 36th Session of World Federation of Scientists, International Seminars on Planetary Emergencies, 18-26 August, Erice, Italy.

[10] Mack, R.L., \& Kelly, M.J. (2004). Equal Justice in the Balance: America's Legal Response to the Emerging Terrorist Threat. Ann Arbor, Michigan: University of Michigan Press.

[11] Haque, M.S. (2002). Government Responses to Terrorism: Critical Views of Their Impact on People and Public Administration. Public Administration Review, 62 (5), 98-108.

[12] Crelinsten, R.D., \& Schmid, A.P. (1992). "Western Responses to Terrorism: A Twenty-Five Year Balance Sheet.” In: Alex P. Schmid (Eds.). Western Responses to Terrorism. Special issue of Terrorism and Political Violence, 4(4), $322-323$.

[13] Alex P. Schmid (1992) Countering terrorism in the Netherlands. Terrorism and Political Violence, 4 (4), 77-109.

[14] Global Regulation. (2015). Organic Law 8/2015, Of July 22, Modifying the System of Protection of Children and Adolescents. Global Regulation. Accessed on July 12, 2020 from https://www.globalregulation.com/translation/spain/615890/organic-law-8-2015\%252c-of-july-22\%252c-modifying-the-system-of-protectionof-children-and-adolescents.html

[15] Federal Law Gazette. (2019). Criminal Code in the version published on 13 November 1998 (Federal Law Gazette I, p. 3322), as last amended by Article 2 of the Act of 19 June 2019 (Federal Law Gazette I, p. 844). The Federal Republic of German.

[16] Media Council of Kenya. [2016). A handbook on reporting terrorism. Media Council of Kenya. Accessed on June 21, 2020 from https://www.mediacouncil.or.ke/en/mck/images/Downloads/A-handbook-on-reporting-terrorism.pdf

[17] Durmaz, H., Seinc, B., Yayala, A.S., \& Ekici, S. (eds.), Understanding and responding to terrorism. Amsterdam: IOS Press

[18] Pedahzur, A., \& Perliger, A. (2009). Jewish terrorism in Israel. Columbia University Press.

[19] Giraldo, J.K., \& Trinkunas, H.A. (2007). Terrorism Financing and State Responses: A Comparative Perspective. Stanford, Calif.: Stanford University Press.

[20] Owuor, J. (n.d.). Anti- Money Laundering \& Combating Financing of Terrorism: Training for Insurance Agents. Accessed on June 11, 2020 from https://www.ira.go.ke/images/updates/anti-money-laundering--cft-training.pdf

[22] Beckman, J. (2016). Comparative legal approaches to homeland security and anti-terrorism. London: Routledge.

[23] Wilkinson, P. (2005). International terrorism, the changing threat and EU responses. Institute for security studies. Eu, Paris. October (84). Chaillot paper.

[24] Mazrui, A. 2002. Afro-Arab Crossfire between the flames of Terrorism and the force of pax-Americana. DPMF (A.A.)

[25] Munene, M. (2012). The Challenge of Al-Shabaab. Africa Review, February 17. http://news.africareview.com/AfricaAt 
[26] Creswell, John W. (2014). Research design: qualitative, quantitative, and mixed methods approaches (4th ed.). Thousand Oaks: SAGE Publications.

[27] Yamane, T. (1973). Statistics: An introductory analysis (3rd Ed.). New York: Harper and Row.

[28] Kothari, B. L. (2007). Research Methodology: Tools and Techniques. ABD Publishers.

[29] Ganor, B. (1998). Defining Terrorism: Is One Man's Terrorist Another Man's Freedom Fighter? (August 19), at http://www.ict.org.il/articles/define.htm.

[31] Jones, S.G., Liepman, A., \& Chandler, N. (2016). Counterterrorism and Counterinsurgency in Somalia: Assessing the Campaign against Al Shabaab. Santa Monica, CA: RAND Corporation.

[32] Kibet, K.R. (2016). Terrorism and Kenya's foreign policy: a contextual analysis, 2016. Master's Thesis. United States International University - Africa.

[33] GoK. (2010). Prevention of Organized Crimes Act 2010. Nairobi: Government Printer.

[34] GoK. (2011). Proceeds of Crime and Anti-Money Laundering Act 2011. Nairobi: Government Printer.

[35] GoK. (2013). Prevention of Terrorism Act 2013. Government Printer, Nairobi.

[36] Osoro, C.M. (2017). Effectiveness of social media in crisis communication: the case of Westgate Mall attack. Master's Thesis. University of Nairobi.

[37] Simon, T., Goldberg, A., Aharonson-Daniel, L., Leykin, D., \& Adini, B. (2014). Twitter in the Cross Fire-The Use of Social Media in the Westgate Mall Terror Attack in Kenya. PLoS ONE, 9(8), e104136.

[38] Gonzales-Herrero, A., \& Smith, S. (2008). Crisis Communications Management 2.0: Organizational Perspective. Journal of Contingencies and Crisis Management, 14(1), 4.

[39] Bransford, S.D. (2015). An Examination of Factors Affecting Information Sharing among Law Enforcement Agencies. Dissertations, 540. Accessed pm August 21, 2020 from https://aquila.usm.edu/dissertations/540

[40] Gatuiku, P. (2016). Countering terrorism in the H of Africa: a case study of Kenya. Master's Thesis. University of Nairobi.

[40] UNHRC. (2015). The Error of Fighting Terror with Terror: Preliminary Report of KNCHR Investigations on Human Rights Abuses in the Ongoing Crackdown against Terrorism. Kenya National Commission on Human Rights. Accessed on January $\quad 5, \quad 2020 \quad$ from: http://www.knchr.org/Portals/0/CivilAndPoliticalReports/Final\%20Disappearances\%20report\%20pdf.pdf

[41] UN General Assembly. (1999). International Convention for the Suppression of the Financing of Terrorism, 9 December, No. 38349. Available at: January 6, 2020 from https://www.refworld.org/docid/3dda0b867.html

[42] UN Security Council. (2001). Security Council resolution 1373. [threats to international peace and security caused by terrorist acts], 28 September 2001. S/RES/1373 (2001), available at: https://www.refworld.org/docid/3c4e94552a.html [accessed 6 January 2020]

[43] Parkinson, J. (2011). The Cost of Inadequate Training. Western Journal of Criminal Justice, $3,1$.

[44] Magogo, S. (2017). The effectiveness of counter terrorism strategies in Kenya: a case study of Eastleigh Location, Nairobi County. Master Thesis, University of Nairobi.

[45] Sang, F.K. (2015). "Kenya", International police cooperation: a world perspective. Daniel J. Koenig and Dilip K. Das. (Eds.). November, 24.

[46] Bakker, E., Maley, W., \& Boeke, S. (2016). "ICCT Research Report NATO Project: Transitioning from Military Interventions to Long-Term Counter-Terrorism Policy." International Centre for Counterterrorism - The Hague.

[47] Wickramasekara, A.P. (2017). Transnational organized crime and new terrorism in Sri Lanka: a nexus? Master's Thesis. Naval Post Graduate School, Monterey, California.

[48] Maluki, P.M. (2019, January 21). How Kenya's security forces made sure they responded better this time. African Arguments. Accessed on September 12, 2020 from https://africanarguments.org/2019/01/21/how-kenya-security-forcesresponded-nairobi-attack/

[49] Shortland, N.D., Sari, H., Palasinski, M., Nader, E., \& Hilland, C. (2018). Murder on Maneuver: Exploring green-on-blue attacks in Afghanistan. Armed Forces and Society.

\footnotetext{
About the Author:

Musoma A. Lusiola is a holder of B.Sc. Military Science, M.A. in International Studies from the University of Nairobi and Master of Arts in Diplomacy Intelligence and Security from Strathmore University. He also holds CSMP Certificate from ISMI and many other certifications in security intelligence. He is a serving Major in the Kenya Defence Forces.
} 